\title{
Examination of Chinese Cruise Tourists' Attributes Using a Choice Experiment
}

\author{
SeYoung Park ${ }^{1}$, Won Seok Lee ${ }^{2, *}$, Joonho Moon ${ }^{3}$ (I) and Jun Heo ${ }^{4}$ \\ 1 Department of Leisure and Tourism, Kyonggi University, 24, Kyonggidae-ro 9-gil, Seodaemun-gu, \\ Seoul 03753, Korea \\ 2 Department of Tourism and Recreation, Kyonggi University, 24, Kyonggidae-ro 9-gil, Seodaemun-gu, \\ Seoul 03753, Korea \\ 3 Department of Tourism Administration, Kangwon National University, Hyoja2-Dong, Kangwon University \\ Rd, Chooncheon 200-701, Korea \\ 4 Global MICE Major, Dongduk Women's University, 60, Hwarang-ro 13-gil, Seongbuk-gu, Seoul 02748, Korea \\ * Correspondence: lws798@kyonggi.ac.kr; Tel.: +82-10-8817-5524
}

Received: 31 May 2019; Accepted: 30 June 2019; Published: 1 July 2019

\begin{abstract}
Several studies have mentioned the differentiation between Western and Asian cultures in terms of people's backgrounds, life styles, and perspectives. In particular, in cruise tourism, tourists from China have shown different behavior from Western tourists. Previous research has investigated the preferences of cruise tourists. However, there have been few systematic studies of their preferences. Thus, it is necessary to examine cultural uniqueness with a systematic method. Therefore, the main purpose of the study is to apply a choice experiment (CE), which is a scientific method for understanding Chinese tourists' preferences for a given attribute as a form of marginal willingness-to-pay, and to identify their priorities. In order to collect the data from an online data platform, the answers from 244 Chinese were used for multinomial logit analysis. The study results demonstrate that the respondents placed the highest value on having a variety of shopping items in duty-free shops on board. Furthermore, room type, percentage of traditional Chinese food served, and touring in ports of call were also statistically significant attributes. The conclusion and the implications of this study will be discussed.
\end{abstract}

Keywords: Chinese cruise tourists; cruise tour preference; cultural difference in cruise tourism; marginal willingness to pay

\section{Introduction}

Recently, the cruise industry worldwide has been growing rapidly, and the number of cruise travelers has also been increasing steadily [1-5]. To be specific, the annual number of cruise tourists increased from 20.9 million in 2012 to 24 million in 2015 worldwide [6]. Of the cruise tourists, Chinese cruise tourists account for a large portion in the cruise market, and their number is continuously increasing [3,7]. According to the Korean Maritime Institute [8], a think tank developing Korean policies on marine affairs, Chinese cruise tourists also accounted for $92 \%$ of inbound cruise travelers to Korea. In particular, Chinese companies such as Shinhwa Life Insurance, Baojian, a company that produces and sells skin-beauty products and daily necessities, and Amway, a multi-level marketing company that sells health, beauty, and home care products, provided cruise tours to Korea to their well-performing employees in the name of incentive tours, with an estimated $(4000$ to 12,000$)$ tourists visiting Korea on such incentive cruise tours [9]. Incentive tours are generally paid for in full by a company, and the amount of individuals' spending is larger than for ordinary forms of tourism, so in turn the mass consumption brings a large economic ripple effect [10]. That is, Korea's cruise industry 
relies heavily on the Chinese market and shows a huge influence from Chinese tourists. Therefore, the Korean cruise industry is trying hard to attract more Chinese incentive tourists [11].

However, in 2017, China imposed a ban on group tours to Korea in response to terminal high-altitude area defense (THAAD) development. The Chinese government also banned cruise tours to Korea, which had a huge impact on the entire Korean cruise tourism industry [12]. Fortunately, the number of Chinese group tourists is on the rise again as of 2019, because of the creation of a political reconciliatory mood between Korea and China [13]. As evidence of this mood, the Chinese travel agency Yingke Tourism has resumed sales of cruise tour packages to Incheon, Korea [14]. The improvement in this situation is likely to serve as a boon for the Korean cruise industry, which has relied heavily on the Chinese market.

Culture and tourism behavior have a close relationship. In other words, individual tourist preferences or behaviors are formed differently, based on idiosyncratic cultural backgrounds $[15,16]$. Similar phenomena are shown in the cruise tourism domain. For example, Mondou and Taunay [3] mentioned that cultural differences between Western and Eastern cultures have resulted in dissimilar preferred tourism contents or patterns among cruise tourists. Even though Chinese tourists have an enormous global market share, academic cruise research has so far centered on the study of tourists belonging to Western culture. In other words, there is a lack of systematic study of cruise-tour attributes reflecting the cultural characteristics of the Chinese, who are a major demander worldwide. In the end, this leads to a lack of understanding of Chinese cruise tourists, which in turn means that inadequate cruise products will be provided $[17,18]$.

Therefore, it is necessary to look systematically at the cruise-tourism attributes favored by Chinese cruise tourist groups. In order to achieve this goal, a choice experiment (CE) is employed in this study. $\mathrm{CE}$ is a representative method to measure the degree of preference for each attribute by employing maximization utility theory [19]. One advantage of CE is that the size of the utility of attributes can be measured by converting the utility to a monetary value, which is called marginal willingness to pay (MWTP) [20]. Given the market share of cruise tourism in Korea and the methodological advantages of $\mathrm{CE}$, the purpose of the study is to estimate the preferences of potential Chinese tourists heading to Korea by applying CE.

\section{Literature Review}

\subsection{Cruise Incentive Tourism in China}

Cruise tourism refers to a tour that allows individuals to travel to several port destinations by ship, enjoying various amenities provided on board and participating in leisure programs [21]. During the cruise tour, tourists could stay a few days on board and enjoy a variety of recreational activities and facilities, including restaurants, shopping, sports, and spas [22]. Because of these characteristics, the cruise industry and tourism have grown rapidly, especially in the past decade, with the number of cruise tourists rising noticeably $[23,24]$. Tourism-product providers and experts see the Chinese as a potential major consumer that in the future could provide a significant opportunity for the cruise industry $[25,26]$. The number of Chinese cruise tourists began to increase in 2006; their cruises spread throughout Asia, including Korea and Japan, as well as Europe, the Mediterranean, and the Caribbean [3,7]. In 2010, 328,000 Chinese tourists participated in a cruise tour, and the number is expected to continue to grow, and to reach 31 million by 2025 [27].

This growth of Chinese cruise tourists was marked by cruise tours to Korea [21]. They accounted for more than 90 percent of cruise tourists visiting Korea in 2016 [8]. In particular, Chinese companies, such as Shinhwa Life Insurance, Baojian, Amway, and Newskin, chose to take large-scale cruise tours to Korea in the form of employee incentive tours [9]. Since companies pay the full amount of travel expenses, individual employees are free from the burden of traveling expenses, and hence are likely to spend more to meet their individual needs than are ordinary travelers. In addition, those on large-scale cruise tours could bring considerable economic ripple effects by spending heavily on cruise-tour goods, 
such as port tours, on-board parties, duty-free shopping, and casinos [28]. For example, Amway estimated that 15,000 employees visited Korea on a reward vacation, and they spent about 16.9 billion Korean Won (KRW) on cruise tours, of which 14 billion KRW (roughly 11.75 million USD) was spent on shopping. The consumption generated economic ripple effects worth 57.7 billion KRW in Korea. For these reasons, the Korean government or suppliers are continuously trying to attract Chinese incentive cruise tourists.

\subsection{Preference of Chinese Cruise Tourists}

Understanding tourists' tendencies and preferences is necessary to drive continued consumption. In other words, recognizing Chinese cruise tourists' preferences is essential for the continued growth of cruise tourism for the Chinese [25,29]. Some studies have emphasized that the preferences of Chinese cruise tourists differ from those of Western tourists [3,30]. For example, Yang [30] conducted a study on which items Chines cruise tourist prefer the most among existing cruise products. He asked respondents what they thought was important by suggesting categories, including accommodation, dining, on-board entertainment programs, shore excursions, and social interactions with other tourists. Most Chinese and Western tourists considered accommodations and dining to be important categories. In contrast, there was a different result for social interaction with other tourists. Generally, tourists from Western cultures showed greater expectations for meeting and interacting with strangers on cruise ships. On the other hand, Chinese tourists regarded communicating with others as a relatively less important part of a cruise tour.

Moreover, the type of meals served by cruise ships also showed a higher preference for eating traditional Chinese food, unlike Western-culture individuals, who prefer to taste different and unique foods from other countries. In addition, the Financial Times [31] mentioned that the Chinese enjoy a boisterous and noisy atmosphere, because they consider it important to see and enjoy things that give them a lively feeling. For this reason, they prefer to watch various exciting music performances and comedy shows, and to participate in games like mahjong, rather than sunbathe like Western cruise tourists prefer to do. Other distinguishable Chinese preferences can be found in shopping and port tours. Chinese tourists showed a high preference for duty-free shopping on board [3]. They have a strong desire to experience seeing and buying expensive luxury brands and various products [32]. Additionally, they tend to like finding gifts for their family, friends, or acquaintances by shopping at duty-free shops [33]. Considering these characteristics of Chinese tourists, the cruise company 'Costa' removed sunbath rooms and swimming pools that are used for western tourists, and expanded shopping spaces for Chinese tourists. They also increased the numbers of duty-free items, and provided shopping opportunities during port tours to satisfy the preference of Chinese tourists [25]. Furthermore, for the Chinese, tourism has traditionally been concentrated on visiting historical sites. Therefore, visiting historical sites or attractions in the port is essential for tourism in the port area. [30]. They tended to spend a lot of time sightseeing in the port's famous tourist attractions, and shopping at local traditional markets or shopping malls [8]. Considering that Chinese cruise tourists' preferences are different from those of Western cruise tourists, it is necessary to systematically find out the preferences of Chinese cruise tourists, in order to be more competitive with them.

\subsection{Stated Preference: Choice Experiment and its Use in a Recreation and Tourism Context}

The stated preference (SP) approach is a systematic method to estimate the economic value of non-market goods based on individuals' preferences for specific products or services [34]. Through $\mathrm{SP}$, it is possible to identify preferences for the attributes of a given product by asking respondents to choose a favorite product that consists of combined attributes [35]. There are two representative methods in SP: the contingent valuation method (CVM) and the choice experiment (CE). Of them, the $\mathrm{CE}$ is a specialized method for identifying the utility respondents attribute to goods and services, and transforming the utility into monetary value [36-38]. In other words, researchers could identify how much more respondents are willing to pay for an attribute as a form of marginal willingness-to-pay 
(MWTP), when increasing one unit of quantity or quality of a product or services' attribute [39]. By comparing the size of MWTPs, researchers could indirectly identify which attributes respondents prefer $[21,40]$.

Because of this advantage, several tourism studies have employed CE to identify preferred attributes and their monetary values. For example, Balcombe, Fraser and Harris [41] conducted a study of airplane preferences, including the width and space between seats, in-flight meals, in-flight entertainment (e.g., seat-back screens, in-flight bar), in-flight drinks, and ticket prices. The study results showed that the width and spacing of seats and the in-flight entertainment are statistically significant, especially with the relatively younger generation, who have a higher preference for in-flight entertainment, whereas the older generation places more value on the width and spacing of seat. Chia-Jung and Pei-Chun [42] identified the determinants of tourists' choice of green hotel attributes. They included attributes as room type; service quality; environmentally cooperative behavior of guests; and green measures such as degree of environmental practices, facilities, and equipment. They concluded that respondents with a high level of green consumption traits are more likely to choose hotels that have a greater number of environmentally friendly attributes.

Hearne and Salinas [43] conducted a study to estimate the preferences of tourists visiting Costa Rica by using a CE. They classified attributes, including accommodation, service, availability of picnic areas and cable car, degree of trail restrictions, and entrance fee. The study result demonstrated that respondents place a higher value on access to trails with low restrictions, and picnic and cable car availability. Another example of applying CE in a tourism context is Masiero, Heo, and Pan's study [44]. They classified hotel attributes, including room views, hotel floors, club accessibility, free mini bar, wireless internet access, cancellation fees, and room prices, finding that first-time visitors to the hotel showed more willingness to pay for room views, club accessibility, and free minibars than repeat visitors.

Given the methodological advantages of $\mathrm{CE}$, we also selected it as a main analytic method to investigate preferences for facilities and programs in Chinese cruise tourism by estimating and comparing their MWTPs.

\section{Method}

\subsection{List of Attributes and Levels}

To identify preferences for attributes of a specific product or service, in-depth review of the attributes is required. In other words, representative attributes and levels that constitute cruise products should be identified to systematically investigate preferences for cruise tour packages for the Chinese. In the study, to identify the preferred characteristics of cruise tourism for Chinese tourists, the attributes and their corresponding levels for the study were chosen based on prior research on cruise tourism, a report published by an official agency, and related newspaper articles $[3,7,17,18,25,26,45]$. After the settlement process, five attributes and three levels of each were finally selected. Moreover, cruise tour prices are also included as a component of a product, which should be included as a baseline to estimate an individual MWTP. The following six attributes were identified: (1) room type, (2) programs, (3) variety of shopping items, (4) tour packages in ports of call, (5) percentage of traditional Chinese food, and (6) price. Table 1 shows the attributes and corresponding levels used in this study.

\subsection{Choice Sets and Experimental Design}

Once the attributes and levels were established, a hypothetical product consisting of different levels of attributes was presented to the respondent, who was asked to select the most preferred product. This product or service combining several attributes is called a profile. The hypothetical Chinese incentive cruise tourism in the study had a total of six attributes, each with three levels. Again, a profile is a set of attributes that includes room type, programs, variety of shopping items, tour packages in ports of call, and percentage of traditional Chinese food. This combined package 
is called a profile. In this study, three profiles, including one opt-out profile ('I would not take A or $\mathrm{B}^{\prime}$ ), made up a choice set. If a respondent did not like either $\mathrm{A}$ or $\mathrm{B}$, he or she could select the opt-out profile.

Table 1. Chinese cruise tourism related attributes and corresponding levels.

\begin{tabular}{cc}
\hline Attributes & Level \\
\hline Room type & $\begin{array}{c}\text { Inside } \\
\text { Ocean view } \\
\text { Suite room }\end{array}$ \\
Programs & $\begin{array}{c}\text { Onboard entertainment activities } \\
\end{array}$ \\
Onboard entertainment activities + sport and fitness programs \\
Onboard entertainment activities + sport and fitness programs + \\
spa and wellness programs
\end{tabular}

Based on the six attributes and their three levels, there are $729(3 \times 3 \times 3 \times 3 \times 3 \times 3)$ possible choice profiles (called full factorial design). However, it is unrealistic to ask respondents for their preferences on all 729 cases in a survey questionnaire. Therefore, instead of providing all combinations, a methodological technique, called a fractional-factorial design, is used to extract a smaller number of representative and efficient linear design profiles. Statistical Package for Social Science (SPSS) was used to derive a fractional-factorial design, and a total of 18 sets were derived. Table 2 shows an example of one of the choice sets:

Table 2. An example of a choice set sent to respondents.

\begin{tabular}{|c|c|c|c|}
\hline Attributes & Profile A & Profile B & Profile C \\
\hline Room type & Inside & Inside & \multirow{6}{*}{ I would not take $A$ or $B$} \\
\hline Programs & $\begin{array}{l}\text { Onboard entertainment } \\
\text { activities + sport and } \\
\text { fitness programs }\end{array}$ & $\begin{array}{l}\text { Onboard entertainment } \\
\text { activities }+ \text { sport and } \\
\text { fitness programs }+ \text { spa } \\
\text { and wellness programs }\end{array}$ & \\
\hline $\begin{array}{l}\text { Variety of shopping } \\
\text { items }\end{array}$ & $\begin{array}{l}\text { Lots of duty-free } \\
\text { shopping items }\end{array}$ & $\begin{array}{l}\text { Moderate duty-free } \\
\text { shopping items }\end{array}$ & \\
\hline $\begin{array}{c}\text { Tour packages in ports } \\
\text { of call }\end{array}$ & $\begin{array}{l}\text { Sightseeing + historical } \\
\text { sites + shopping }\end{array}$ & Sightseeing & \\
\hline $\begin{array}{l}\text { Percentage of traditional } \\
\text { Chinese food }\end{array}$ & $100 \%$ & $66 \%$ & \\
\hline Price (CNY) & 4777 & 6825 & \\
\hline
\end{tabular}




\subsection{Theories of Choice Experiment}

Random utility maximization theory (RUT) is a main theoretic underpinning of CE [46,47]. According to RUT, an individuals' utility can be expressed in two sections by an equation between an observed component and an unobserved random component. Individuals' utility is derived not only from the attributes of observable goods/services, but also from unobservable characteristics. The following equation shows the utility function for alternative $j$ of the $j^{\text {th }}$ individual:

$$
U_{i j}=V_{i j}+\varepsilon_{i j}
$$

where, $U_{i j}$ indicates the indirect utility acquired when choosing i alternatives. As shown in Equation (1), utility is distinguished by two parts: $V_{i j}$ is the observable utility or the deterministic component of utility, and $\varepsilon_{i j}$ is the unobserved stochastic component or unobserved idiosyncrasies of personal taste, which are treated by researchers as a random variable because of uncertainty factors [48].

The unobservable error component explains that consumers' preferences are not always rational across the population [49]. That is, this error term stands for the unexplained differences in an action between individuals that the researcher cannot observe. Based on RUT, respondent $i$ chooses alternative $j(1,2, \ldots, \mathrm{m})$ if the utility of selecting alternative $j$ is greater than that of selecting $k\left(U_{\mathrm{ij}}>U_{\mathrm{ik}}\right.$ for all $j \neq k$ ). The equation of probability of choosing an alternative is shown as follows:

$$
P_{i j}=\operatorname{Pr}\left\{U_{i j} \geq U_{i k}\right\}=\left\{V_{i j}-V_{i k} \geq \varepsilon_{i j}-\varepsilon_{i k} ; \mathrm{j} \neq \mathrm{k}, \mathrm{j}, \mathrm{k} \in J_{i}\right\}
$$

McFadden [47] argued that if random components, $\varepsilon_{i j}$ and $\varepsilon_{i k}$ (unobserved stochastic components) in Equation (2), are assumed to follow the Gambel distribution (independently and identically distributed across alternatives), the probability can result in a conditional (or multinomial) logit model. The probability that an individual $i$ selects alternative $j$ is described as follows:

$$
\mathrm{P}_{i j}=\exp \left(\mu \mathrm{V}_{i j}\right) / \sum \exp \left(\mu V_{i k}\right)
$$

where, $\mu$ is a scale parameter, which is typically set to one for parameter estimation. Again, this logit model hypothesizes the independence of irrelevant alternatives (IIA) property, signifying that an individual's choice does not depend on any other alternatives [50]. The parameters are estimated by log maximum likelihood estimation, which is as follows:

$$
\ln L=\sum_{i=1}^{n} \sum_{j=1}^{m} \delta_{i j} \ln P_{i j}
$$

where, $\delta_{i j}$ is a dummy variable such that $\delta_{i j}=1$ if alternative $j$ is chosen, and $\delta_{i j}=0$ otherwise. Once model parameters are estimated, the implicit price for each attribute can be derived by calculating the following:

$$
\text { Marginal willingness to pay for attribute }=\frac{\beta_{\text {non-cost-attribute }}}{-\beta_{\text {cost-attribute }}}
$$

\subsection{Survey and Data Collection}

The survey questionnaire was confirmed by experts in the field of tourism and the cruise industry, and was translated into Chinese language by a Chinese translator to check its clarity and fluency. We uploaded our questionnaires in 'Wen Juan Xing', a Chinese online survey platform (https://www.wjx.cn/) in order to collect data. 'Wen Juan Xing' is a data platform used by more than 30,000 companies and more than $90 \%$ of universities in China. Once respondents clicked the survey through QR code or internet link address, they were then asked to answer choice questions. Initially, a total of 303 surveys were distributed from May 8th to 10th, 2019, but 59 were excluded because of 
missing responses. Ultimately, 244 were used for data analysis. Appendix A presents the measurement used in this study.

\section{Results}

\section{Estimation Results of the Study Model}

Table 3 shows the results of a frequency analysis of respondents' demographic characteristics. There were 126 (51.6\%) females and 118 (48.4\%) males; thus, the ratio of females was slightly higher. For age groups, there were 107 (43.9\%) in their 30s, 93 (38.1\%) in their 20s, $38(15.6 \%)$ in their 40s, and $6(2.5 \%)$ over 50 s. In terms of academic background, $157(64.3 \%)$ respondents graduated from a university or college, representing the largest group, followed by those attending university and college at $47(19.3 \%)$. For monthly average income, $86(35.2 \%)$ were between price (CNY) 5000 and 8000, 66 (27\%) respondents were between CNY 8000 and 12,000, 57 (23.4\%) were between CNY 2000 and 5000, 23 (9.4\%) were more than CNY 12,000, and 12 (4.9\%) were less than CNY 2000.

Table 3. Demographic information.

\begin{tabular}{cccc}
\hline & & Frequency & Percentage (\%) \\
\hline \multirow{2}{*}{ Gender } & Male & 118 & 48.4 \\
& Female & 126 & 51.6 \\
\hline \multirow{2}{*}{ Age } & $20 \mathrm{~s}$ & 93 & 38.1 \\
& $30 \mathrm{~s}$ & 107 & 43.9 \\
& $40 \mathrm{~s}$ & 38 & 15.6 \\
& Over 50s & 6 & 2.5 \\
\hline \multirow{3}{*}{ Academic background } & Less than high school & 19 & 7.8 \\
& Graduated from university/college & 47 & 19.6 \\
& Graduate school & 21 & 64.3 \\
& Less than 2000 & 12 & 8.6 \\
\hline \multirow{2}{*}{ Price (CNY) } & $2000-5000$ & 57 & 4.9 \\
& $5000-8000$ & 86 & 23.4 \\
& $8000-12,000$ & 66 & 35.2 \\
& More than 12,000 & 23 & 27.0 \\
& & 9.4 \\
\hline
\end{tabular}

Multinomial analysis was used for the data analysis. Table 4 shows the result of the multinomial logit model of this study. The hypothesis tests were conducted at $0.05 \%$ level, through maximum likelihood estimation and five attributes, excluding program attributes, were statistically significant. In addition, a variable called 'alternative specific constant' (ASC), the utility that individuals obtain when choosing A or B package over the opt-out choice (neither A nor B), is included in the study model.

Table 4 shows that the estimated coefficient of 'room type' is 0.371 with a corresponding $p<0.001$. This indicates that there is a higher chance of choosing a product when the quality of the room is improved. Similarly, other variables, except programs, were statistically significant, which could be interpreted as meaning that respondents preferred to increase the level of attributes. On the other hand, 'programs' is not significant $(p=0.246)$, demonstrating that quality improvement or degradation of the programs would be interpreted as not affecting the choice of respondents. For the cruise price, the parameter was negative and significant, meaning that an increase of cruise price was not preferred by respondents. 
Table 4. Estimation results of the main attributes.

\begin{tabular}{ccccc}
\hline Parameter & Estimates & Standard Error & $t$-Value & $\operatorname{Pr}>$ \\
\hline Room type & $0.371^{* *}$ & 0.041 & 8.91 & 0.000 \\
Programs & -0.047 & 0.041 & -1.16 & 0.246 \\
Variety of shopping items & $0.389^{* *}$ & 0.042 & 9.23 & 0.000 \\
Tour packages in ports of call & $0.157^{* *}$ & 0.042 & 3.68 & 0.000 \\
Percentage of traditional Chinese food & $0.240^{* *}$ & 0.041 & 5.87 & 0.000 \\
Price & $-0.0005016^{* *}$ & 0.0000222 & -22.58 & 0.000 \\
Alternative specific constant (ASC) & $5.189^{* *}$ & 0.200 & 25.86 & 0.000 \\
\hline \multicolumn{4}{c}{ Log-Likelihood $=-2974.4151$} \\
\\
McFadden Pseudo $R^{2}=0.2757$ \\
Number of observations $=6453$ \\
** indicates significance at 0.05 level.
\end{tabular}

Table 5 indicates the marginal willingness-to-pay for each attribute. MWTP is the amount an individual is willing to additionally pay when increasing the level of a given attribute. According to Table 5, 'variety of shopping items' (133,358 KRW) had the highest MWTP among the six attributes, followed by 'room type' (127,187 KRW), 'percentage of traditional Chinese food' (82,277 KRW), and 'tour packages in ports of call' (53,823 KRW). The result implies that respondents place the highest value on 'variety of shopping items.' In other words, it can be indirectly interpreted that the Chinese consider 'variety of shopping items' to be the most important attribute in a cruise tour to Korea.

Table 5. Marginal willingness-to-pay.

\begin{tabular}{cc}
\hline Attributes & Price \\
\hline Room type & $127,187 \mathrm{KRW}$ \\
Variety of shopping items & $133,358 \mathrm{KRW}$ \\
Tour packages in ports of call & $53,823 \mathrm{KRW}$ \\
Percentage of traditional Chinese food & $82,277 \mathrm{KRW}$ \\
\hline
\end{tabular}

\section{Discussion}

Michael Thamm, the CEO of the world's leading cruise company, 'Costa', maintains that Chinese cruise tourism should be seen as a promising market [51]. In Korea, the cruise market is also growing-Chinese cruise tourists visiting the country accounted for about 92 percent of all cruise tourists by 2016 [52]. In particular, numerous Chinese companies offer large-scale cruise tours to Korea as incentives for employees. The companies pay for employees' cruise trips, so incentive tourists tend to spend relatively more than ordinary tourists, which has a huge economic impact on tourist attractions [28].

The research on cruise tourists has focused mainly on Western tourists; however, research to understand the Chinese market, which is a big part of the demand for global cruise markets, has not been enough $[17,18]$. Some studies have argued that the cultural differences between Chinese and Western tourists would cause idiosyncrasies in preferences for cruise attributes, such as activities or programs [3,29]. Thus, a systematic study of cruise tourism preferences for Chinese tourists reflecting the cultural characteristics is needed. Therefore, the purpose of the study was to systematically understand the preferences for cruise tour product attributes through a CE for potential Chinese incentive cruise tourists.

Through literature review of prior studies and expert interviews, the following six cruise tour attributes and their corresponding levels were chosen for the study. Room type (inside, ocean view, and suite room), programs (onboard entertainment activities, onboard entertainment activities plus sport and fitness programs, and onboard entertainment activities plus sport and fitness programs plus spa and massage programs), variety of shopping items (less, moderate, and lots), percentage of 
traditional Chinese food served of $(33,66$, and 100) \%, and price of CNY $(4777,6825,8873)$. A total of $729\left(3^{6}\right)$ cruise products could possibly be combined based on the number of attributes and levels. However, it is physically impossible to identify respondents' preferences for all combinations. Therefore, data were gathered by the minimum representative combinations through a fractional-factorial design, which enabled the researchers to statistically verify attributes, even without using all combinations. The collected data were statistically analyzed by the multinomial logit analysis. Five attributes, including room type, programs, variety of shopping items, tour packages in ports of call, percentage of traditional Chinese food served, and price, were statistically significant, except for programs. This result indicates that a one-unit increase of room type, variety of shopping items, tour packages in ports of call, and percentage of traditional Chinese food changes would increase the likelihood of choosing the products.

For the MWTPs, how much individuals were willing to pay as a given attribute's condition increased, and the variety of shopping items had the highest value among the five attributes in this study. In other words, respondents are more likely to place the highest value on the diversity of shopping offered on cruise ships. This conclusion is externally validated by previous studies. According to a survey of foreign cruise tourists released by the Korea Tourism Organization (KTO) in $2013,87.4 \%$ of Chinese tourists shopped at cruise duty-free shops, whereas less than $10 \%$ of tourists from the U.S., Australia, and New Zealand participated in duty-free shopping [51]. Chinese tourists preferred to purchase luxury brand products in duty-free shopping, more so than did other cultural tourists $[3,32,33]$. Therefore, given the report published by the public sector and the validity of the study, it is important to build various duty-free shops on cruise ships to satisfy Chinese tourists on cruise tours. Therefore, it can be concluded that Chinese cruise tourists prefer to have luxurious experience by shopping offered on cruise ship.

Second, the type of room was also identified as an important attribute. A cabin is considered an important attribute for Chinese tourists, as well as for overall cruise tourists, as shown by numerous prior studies of cruise tourism $[21,25]$. Since cruise tourists have to stay in a limited space, they prefer a cabin where they can see the ocean, or a suite with balconies and luxurious furniture, because, unlike ordinary trips, cruise tourists are more likely to want a luxurious and unique experience while participating in a tourism cruise [52-55].

Given the size of MWTPs, the proportion of traditional Chinese meals served on board is preferred. This is a conclusion similar to those from earlier studies. For example, Chang, Kivela, and Mak's study [45] found that while traveling abroad, the Chinese prefer to eat something that is routine and friendly. In addition, during cruise tours, Chinese tend to prefer Chinese local cuisine to exotic foreign cuisine, whereas Western cruise tourists prefer to have a variety of international foreign cuisine while on a cruise [17].

Finally, the port tour, which consists of tourist attractions, historical sites, and shopping, was also found to be a preferred attribute. Sun et al. [25] also suggests that for the Chinese, sightseeing at a famous destination of a port is a typical motivation for cruise tourism. At the same time, the Chinese think it is important to broaden their horizons by visiting new historical and cultural sites [30]. In this regard, Chinese tourists find it important to gain new knowledge by visiting major destinations through cruise tours. Therefore, various port-tour programs will have to be prepared to satisfy the preferences of Chinese cruise tourists.

In contrast, the results indicated that programs, such as shows, casinos, sports, or spas, are relatively less preferable attributes. This finding is similar to the results of Chen, Neuts, Nijkamp, and Liu [56]. They examined the determinants of cruise demand according to motivation, preference and intention and indicated that Chinese placed the lowest value on sports facilities such as running track, golf, climbing walls and so on. In addition, based on the cruise schedule suggested by Princess Cruise [57], cruise tourists spend 24 hours on the sea from Shanghai in China to Busan and Jeju in Korea. This is a relatively shorter time period than cruises to California or Hawaii, which spend more than 48 hours at sea. In this regard, cruise tours to Korea offer a relatively short time period to participate in 
various programs on board, which is reflected in the study results. Therefore, Chinese cruise tourists will tend to focus on shopping and port tours, rather than on securing diversity in shipboard programs.

\section{Implication}

This study presents the following practical implications. First, it is necessary to organize diverse duty-free shopping items on the ship. In other words, considering the characteristics of Chinese tourists' preference for shopping activities during cruise tours, service providers need to identify and prepare their preferred brands and items. Second, for accommodation, a method for increasing the percentage of ocean views or suites should be considered in the ship design stage, or an attractive pricing policy should be implemented to prevent dissatisfaction of the inside room guest. Additionally, for Chinese tourists, whose degree of avoidance of uncertainty seems to be large, Chinese-style meals should be served more often. For example, a service provider will likely have to focus on the Chinese tourists' favorite items, including drinks, desserts, and snacks, as well as main foods. Finally, considering Chinese cruise tourists' preference for port tours, visits to various types of tourist attractions will have to be included in the port tours. Furthermore, the satisfaction of Chinese cruise tourists will be increased by not only providing Chinese-speaking guides to explain landmarks and historical sites, but also providing pick-up and drop-off services to conveniently move tourists from ship to destinations. Furthermore, guaranteeing adequate time for attractions would be necessary as well.

Additionally, the results of the study will help to the sustainable development of the cruise tourism industry as mentioned in several prior studies [58-60]. The literature stated that a strategic approach is required for continuous sales of cruise tourism such as discounting price or provision of higher service quality (from the perspective of service providers). Additionally, efforts to establish a regional absorption system of economic benefits from cruise tourism or minimize environmental damages are necessary for sustainable development of the cruise industry [58,61].

Given this argument, this study could guide the Korean cruise industry regarding Chinese tourists to achieve sustainable development. In other words, the degree of importance of preference attributes would be identified based on the study results, which would contribute to the efficient operation of cruise companies. Furthermore, this would eventually lead to a contribution to the sustainability of the cruise industry. For academic implications, the following points can be suggested. First, this study is meaningful in that the study results help one to understand the preferred attributes for Chinese cruise tourists, who are a major consumer of the cruise market around the world. Second, the application of $\mathrm{CE}$, a specialized research method that identifies the preferences of the subjects, could be considered to be a methodological contribution of the study.

However, the present study has some limitations. Theoretically, CE includes some unrealistic assumptions about the choice mechanism of respondents, which are called the irrelevant-alternatives properties (IIA) [49]. Therefore, an advanced econometric model, such as mixed-logit, which theoretically mitigates the IIA assumption, would be recommended for further studies.

Author Contributions: Conceptualization, S.P. and W.S.L.; methodology, J.M., and W.S.L.; formal analysis, S.P., W.S.L. and J.M.; investigation, S.P. and W.S.L.; resources, J.M. and W.S.L.; data curation, S.P., and W.S.L.; writing-original draft preparation, S.P.; writing—review and editing, W.S.L., J.M. and J.H.; visualization, W.S.L. and J.M.; supervision, W.S.L. project administration, W.S.L. J.M. and J.H.

Funding: This research received no external funding.

Conflicts of Interest: The authors declare no conflict of interest.

\section{Appendix A}

From the next question, please choose your preferred cruise tour choice set among (1), (2), (3). Q1. Please select one of (1), (2), or (3), and mark. 


\begin{tabular}{|c|c|c|c|}
\hline Attribute & (1) & (2) & (3) \\
\hline Room type & Inside & Inside & \\
\hline Programs & $\begin{array}{l}\text { Onboard entertainment } \\
\text { activities + sport and } \\
\text { fitness programs }\end{array}$ & $\begin{array}{l}\text { Onboard entertainment } \\
\text { activities }+ \text { sport and } \\
\text { fitness programs }+ \text { spa } \\
\text { and wellness programs }\end{array}$ & \\
\hline $\begin{array}{l}\text { Variety of shopping } \\
\text { items }\end{array}$ & $\begin{array}{l}\text { Lots of duty-free } \\
\text { shopping items }\end{array}$ & $\begin{array}{l}\text { Moderate duty-free } \\
\text { shopping items }\end{array}$ & I would not take A or B \\
\hline $\begin{array}{c}\text { Tour packages in ports of } \\
\text { call }\end{array}$ & $\begin{array}{l}\text { Sightseeing + historical } \\
\text { sites + shopping }\end{array}$ & Sightseeing & \\
\hline $\begin{array}{l}\text { Percentage of traditional } \\
\text { Chinese food }\end{array}$ & $100 \%$ & $66 \%$ & \\
\hline Price $(\mathrm{CNY})$ & 4777 & 8873 & \\
\hline
\end{tabular}

Q2. Please select one of (1), (2), or (3), and mark.

\begin{tabular}{|c|c|c|c|}
\hline Attribute & (1) & (2) & (3) \\
\hline Room type & Ocean view & Ocean view & \\
\hline Programs & $\begin{array}{l}\text { Onboard entertainment } \\
\text { activities }+ \text { sport and } \\
\text { fitness programs }+ \text { spa } \\
\text { and wellness programs }\end{array}$ & $\begin{array}{l}\text { Onboard entertainment } \\
\text { activities + sport and } \\
\text { fitness programs }\end{array}$ & \\
\hline $\begin{array}{c}\text { Variety of shopping } \\
\text { items }\end{array}$ & $\begin{array}{l}\text { Moderate duty-free } \\
\text { shopping items }\end{array}$ & $\begin{array}{l}\text { Moderate duty-free } \\
\text { shopping items }\end{array}$ & I would not take A or B \\
\hline $\begin{array}{c}\text { Tour packages in ports of } \\
\text { call }\end{array}$ & $\begin{array}{l}\text { Sightseeing + historical } \\
\text { sites + shopping }\end{array}$ & $\begin{array}{c}\text { Sightseeing }+ \text { historical } \\
\text { sites }\end{array}$ & \\
\hline $\begin{array}{l}\text { Percentage of traditional } \\
\text { Chinese food }\end{array}$ & $33 \%$ & $33 \%$ & \\
\hline Price $(\mathrm{CNY})$ & 4777 & 8873 & \\
\hline
\end{tabular}

Q3. Please select one of (1), (2), or (3), and mark.

\begin{tabular}{|c|c|c|c|}
\hline Attribute & (1) & (2) & (3) \\
\hline Room type & Ocean view & Ocean view & \\
\hline Programs & $\begin{array}{l}\text { Onboard entertainment } \\
\text { activities + sport and } \\
\text { fitness programs }\end{array}$ & $\begin{array}{l}\text { Onboard entertainment } \\
\text { activities }+ \text { sport and } \\
\text { fitness programs }+ \text { spa } \\
\text { and wellness programs }\end{array}$ & \\
\hline $\begin{array}{l}\text { Variety of shopping } \\
\text { items }\end{array}$ & $\begin{array}{l}\text { Lots of duty-free } \\
\text { shopping items }\end{array}$ & $\begin{array}{l}\text { Less duty-free shipping } \\
\text { items }\end{array}$ & I would not take A or B \\
\hline $\begin{array}{c}\text { Tour Ppackages in ports } \\
\text { of call }\end{array}$ & Sightseeing & Sightseeing & \\
\hline $\begin{array}{l}\text { Percentage of traditional } \\
\text { Chinese food }\end{array}$ & $100 \%$ & $100 \%$ & \\
\hline Price $(\mathrm{CNY})$ & 6825 & 8873 & \\
\hline
\end{tabular}


Q4. please select one of (1), (2), or (3), and mark.

\begin{tabular}{|c|c|c|c|}
\hline Attribute & (1) & (2) & (3) \\
\hline Room type & Ocean view & Inside & \\
\hline Programs & $\begin{array}{c}\text { Onboard entertainment } \\
\text { activities }\end{array}$ & $\begin{array}{l}\text { Onboard entertainment } \\
\text { activities + sport and } \\
\text { fitness programs }\end{array}$ & \\
\hline $\begin{array}{c}\text { Variety of shopping } \\
\text { items }\end{array}$ & $\begin{array}{l}\text { Lots of duty-free } \\
\text { shopping items }\end{array}$ & $\begin{array}{l}\text { Less duty-free shipping } \\
\text { items }\end{array}$ & I would not take $A$ or $B$ \\
\hline $\begin{array}{c}\text { Tour packages in ports of } \\
\text { call }\end{array}$ & $\begin{array}{c}\text { Sightseeing + historical } \\
\text { sites }\end{array}$ & $\begin{array}{c}\text { Sightseeing }+ \text { historical } \\
\text { sites }\end{array}$ & \\
\hline $\begin{array}{l}\text { Percentage of traditional } \\
\text { Chinese food }\end{array}$ & $66 \%$ & $33 \%$ & \\
\hline Price $(\mathrm{CNY})$ & 4777 & 6825 & \\
\hline
\end{tabular}

Q5. Please select one of (1), (2), or (3), and mark.

\begin{tabular}{|c|c|c|c|}
\hline Attribute & (1) & (2) & (3) \\
\hline Room type & Inside & Suite room & \\
\hline Programs & $\begin{array}{l}\text { Onboard entertainment } \\
\text { activities }\end{array}$ & $\begin{array}{l}\text { Onboard entertainment } \\
\text { activities + sport and } \\
\text { fitness programs }\end{array}$ & \\
\hline $\begin{array}{c}\text { Variety of shopping } \\
\text { items }\end{array}$ & $\begin{array}{l}\text { Less duty-free shipping } \\
\text { items }\end{array}$ & $\begin{array}{l}\text { Less duty-free shipping } \\
\text { items }\end{array}$ & I would not take $A$ or $B$ \\
\hline $\begin{array}{c}\text { Tour packages in ports of } \\
\text { call }\end{array}$ & Sightseeing & $\begin{array}{l}\text { Sightseeing + historical } \\
\text { sites + shopping }\end{array}$ & \\
\hline $\begin{array}{l}\text { Percentage of traditional } \\
\text { Chinese food }\end{array}$ & $33 \%$ & $66 \%$ & \\
\hline Price $(\mathrm{CNY})$ & 4777 & 8873 & \\
\hline
\end{tabular}

Q6. please select one of (1), (2), or (3), and mark.

\begin{tabular}{cccc}
\hline Attribute & (1) & (2) \\
\hline Room type & $\begin{array}{c}\text { Suite room } \\
\text { Onboard entertainment } \\
\text { activities }\end{array}$ & $\begin{array}{c}\text { Ocean view } \\
\text { Onboard entertainment } \\
\text { activities }\end{array}$ \\
Variety of shopping & $\begin{array}{c}\text { Moderate duty-free } \\
\text { shopping items }\end{array}$ & $\begin{array}{c}\text { Less duty-free shipping } \\
\text { items }\end{array}$ & items \\
Tour packages in ports of & Sightseeing + historical & Sightseeing + historical & I would not take A or B \\
call & sites & sites + shopping & \\
Percentage of traditional & $100 \%$ & $66 \%$ & \\
Chinese food & 6825 & 6825 & \\
Price (CNY) & &
\end{tabular}


Q7. please select one of (1), (2), or (3), and mark.

\begin{tabular}{cccc}
\hline Attribute & (1) & (2) & (3) \\
\hline Room type & $\begin{array}{c}\text { Suite room } \\
\text { Onboard entertainment } \\
\text { activities + sport and } \\
\text { fitness programs } \\
\text { Moderate duty-free } \\
\text { shopping items }\end{array}$ & $\begin{array}{c}\text { Suite room } \\
\text { Onboard entertainment } \\
\text { activities }\end{array}$ & \\
shopping items & I would not take A or B \\
Tour packages in ports of & Sightseeing & Sightseeing & \\
call & $66 \%$ & $33 \%$ & \\
Percentage of traditional & 4777 & 8873 & \\
Chinese food & Price (CNY) & &
\end{tabular}

Q8. Please select one of (1), (2), or (3), and mark.

\begin{tabular}{|c|c|c|c|}
\hline Attribute & (1) & (2) & (3) \\
\hline Room type & Inside & Suite room & \\
\hline Programs & $\begin{array}{c}\text { Onboard entertainment } \\
\text { activities }\end{array}$ & $\begin{array}{l}\text { Onboard entertainment } \\
\text { activities }+ \text { sport and } \\
\text { fitness programs }+ \text { spa } \\
\text { and wellness programs }\end{array}$ & \\
\hline $\begin{array}{c}\text { Variety of shopping } \\
\text { items }\end{array}$ & $\begin{array}{l}\text { Moderate duty-free } \\
\text { shopping items }\end{array}$ & $\begin{array}{l}\text { Less duty-free shipping } \\
\text { items }\end{array}$ & I would not take A or B \\
\hline $\begin{array}{c}\text { Tour packages in ports of } \\
\text { call }\end{array}$ & $\begin{array}{l}\text { Sightseeing + historical } \\
\text { sites + shopping }\end{array}$ & $\begin{array}{l}\text { Sightseeing }+ \text { historical } \\
\text { sites }\end{array}$ & \\
\hline $\begin{array}{l}\text { Percentage of traditional } \\
\text { Chinese food }\end{array}$ & $100 \%$ & $100 \%$ & \\
\hline Price $(\mathrm{CNY})$ & 8873 & 4777 & \\
\hline
\end{tabular}

Q9. Please select one of (1), (2), or (3), and mark.

\begin{tabular}{|c|c|c|c|}
\hline Attribute & (1) & (2) & (3) \\
\hline Room type & Inside & Suite room & \\
\hline Programs & $\begin{array}{l}\text { Onboard entertainment } \\
\text { activities + sport and } \\
\text { fitness programs + spa } \\
\text { and wellness programs }\end{array}$ & $\begin{array}{l}\text { Onboard entertainment } \\
\text { activities + sport and } \\
\text { fitness programs }+ \text { spa } \\
\text { and wellness programs }\end{array}$ & \\
\hline $\begin{array}{c}\text { Variety of shopping } \\
\text { items }\end{array}$ & $\begin{array}{c}\text { Lots of duty-free } \\
\text { shopping items }\end{array}$ & $\begin{array}{c}\text { Lots of duty-free } \\
\text { shopping items }\end{array}$ & I would not take $A$ or $B$ \\
\hline $\begin{array}{c}\text { Tour packages in ports of } \\
\text { call }\end{array}$ & $\begin{array}{c}\text { Sightseeing }+ \text { historical } \\
\text { sites }\end{array}$ & $\begin{array}{l}\text { Sightseeing + historical } \\
\text { sites + shopping }\end{array}$ & \\
\hline $\begin{array}{l}\text { Percentage of traditional } \\
\text { Chinese food }\end{array}$ & $66 \%$ & $33 \%$ & \\
\hline Price $(\mathrm{CNY})$ & 8873 & 6825 & \\
\hline
\end{tabular}

\section{References}

1. Douglas, A.C.; Mills, J.E.; Phelan, K.V. Smooth sailing? Passengers' assessment of cruise brand equity. J. Travel Tour. Mark. 2010, 27, 649-675. [CrossRef]

2. Marti, B.E. Trends in world and extended-length cruising (1985-2002). Marine Policy 2004, 28, 199-211. [CrossRef] 
3. Mondou, V.; Taunay, B. The adaptation strategies of the cruise lines to the Chinese tourists. Turizam Međunarodni Znanstveno-stručni Časopis 2011, 60, 43-54.

4. Polat, N. Technical innovations in cruise tourism and results of sustainability. Proc.-Soc. Behav. Sci. 2015, 195, 438-445. [CrossRef]

5. Del Chiappa, G.; Abbate, T. Island cruise tourism development: A resident's perspective in the context of Italy. Curr. Issues Tour. 2016, 19, 1372-1385. [CrossRef]

6. Chen, C.A. How can Taiwan create a niche in Asia's cruise tourism industry? Tour. Manag. 2016, 55, 173-183. [CrossRef]

7. Josiam, B.; Huang, T.; Spears, D.; Kennon, L.; Bahulkar, G. Understanding ethnic Chinese travelers on North American cruise tours: Motivations, perceptions, and satisfaction of cruisers. J. Chi. Tour. Res. 2009, 5, 77-101. [CrossRef]

8. Korea Maritime Institute. Available online: https://www.kmi.re.kr/web/trebook/view.do?rbsIdx=273\&idx=29 (accessed on 27 April 2019).

9. Korea Joonghang Daily. Available online: http://koreajoongangdaily.joins.com/news/article/article.aspx?aid= 3030600 (accessed on 27 April 2019).

10. Pan, G.W.; Scott, N.; Laws, E. Understanding and sharing knowledge of new tourism markets: The example of Australia's inbound Chinese tourism. J. Quali. Assu. Hospi. Tour. 2006, 7, 99-116. [CrossRef]

11. Sheraton Walkerhill offers 'hansik' for 15,000 Chinese visitors. The Korea Times. Available online: http://www.koreatimes.co.kr/www/nation/2018/11/113_158838.html (accessed on 25 April 2019).

12. Jeju Losing Luster as Tourist Destination. The Korea Times. Available online: https://www.koreatimes.co.kr/ www/culture/2019/02/141_263681.html (accessed on 25 April 2019).

13. Business Korea. China's Largest Online Travel Company Resumes Selling S. Korean Tour Packages. Available online: http://www.businesskorea.co.kr/news/articleView.html?idxno=30742 (accessed on 25 April 2019).

14. Chosun.com. Available online: http://news.chosun.com/site/data/html_dir/2019/04/06/2019040600213.html? utm_source=naver\&utm_medium=original\&utm_campaign=news (accessed on 25 April 2019).

15. Reisinger, Y.; Turner, L.W. Cultural differences between Asian tourist markets and Australian hosts, Part 1. J. Travel Res. 2002, 40, 295-315. [CrossRef]

16. Li, X.R.; Lai, C.; Harrill, R.; Kline, S.; Wang, L. When east meets west: An exploratory study on Chinese outbound tourists' travel expectations. Tour. Manag. 2011, 32, 741-749. [CrossRef]

17. Lyu, J.; Hu, L.; Hung, K.; Mao, Z. Assessing Servicescape of Cruise Tourism: The Perception of Chinese tourists; Research paper; Emerald Publishing Limited: Bingley, UK, 2017; pp. 2556-2572.

18. Hung, K.; Wang, S.; Guillet, B.D.; Liu, Z. An overview of cruise tourism research through comparison of cruise studies published in English and Chinese. Int. J. Hosp. Manag. 2019, 77, 207-216. [CrossRef]

19. Adamowicz, W.; Louviere, J.; Williams, M. Combining revealed and stated preference methods for valuing environmental amenities. J. Environ. Econ. Manag. 1994, 26, 271-292. [CrossRef]

20. Dimitropoulos, A.; Kontoleon, A. Assessing the determinants of local acceptability of wind-farm investment: A choice experiment in the Greek Aegean Islands. Energy Policy 2009, 37, 1842-1854. [CrossRef]

21. Lee, M.K.; Yoo, S.H. Using a Choice Experiment (CE) to value the attributes of cruise tourism. J. Travel. Tour. Mark. 2015, 32, 416-427. [CrossRef]

22. Xie, H.J.; Kerstetter, D.L.; Mattila, A.S. The attributes of a cruise ship that influence the decision making of cruisers and potential cruisers. Int. J. Hosp. Manag. 2012, 31, 152-159. [CrossRef]

23. Cruisemarketwatch.com. Growth of the Ocean Cruise Line Industry. Available online: http://www. cruisemarketwatch.com/growth/ (accessed on 27 April 2019).

24. Rodrigue, J.P.; Notteboom, T. The geography of cruises: Itineraries, not destinations. Appl. Geogr. 2013, 38, 31-42. [CrossRef]

25. Sun, X.; Feng, X.; Gauri, D.K. The cruise industry in China: Efforts, progress and challenges. Int. J. Hosp. Manag. 2014, 42, 71-84. [CrossRef]

26. Pino, G.; Peluso, A.M. The development of cruise tourism in emerging destinations: Evidence from Salento, Italy. Tour. Hosp. Res. 2018, 18, 15-27. [CrossRef]

27. Peisley, T. Cruising at the Crossroads: Could Regulators Succeed where the Global Economic Crisis Failed and Put an End to Growth? A Worldwide Analysis to 2025. Available online: https://www.worldcat.org/title/cruising-at-the-crossroads-could-regulators-succeed-where-the-global- 
economic-crisis-failed-and-put-an-end-to-growth-a-worldwide-analysis-to-2025/oclc/757404461 (accessed on 28 June 2019).

28. Korea Culture and Tourism Institute. A Study on Revitalizing Cruise: Focused on a Destination of a Cruise Tour and Shore Excursion Program. Available online: https://know.tour.go.kr/ptourknow/knowplus/kcti/ detail.do?seq=101948 (accessed on 28 June 2019).

29. Hung, K. Understanding the cruising experience of Chinese travelers through photo-interviewing technique and hierarchical experience model. Tour. Manag. 2018, 69, 88-96. [CrossRef]

30. Yang, Y. What Chinese Cruisers Want: An Analysis of Product Preferences? Available online: https: //scholarcommons.usf.edu/cgi/viewcontent.cgi?article=6088\&context=etd (accessed on 28 June 2019).

31. Financial Times. On Board China's First Luxury Cruise Liner. Available online: https://www.ft.com/content/ 9a491018-e9c1-11e2-bf03-00144feabdc0\#axzz2sHxCXXSn (accessed on 30 April 2019).

32. Lin, C.-J. Chinese tourists in Taiwan: Motivation and satisfaction. World J. Manag. 2014, 1, 20-35. [CrossRef]

33. Guo, Y.; Seongseop Kim, S.; Timothy, D.J. Development characteristics and implications of Mainland Chinese outbound tourism. Asia Pac. J. Tour. Res. 2007, 12, 313-332. [CrossRef]

34. Hensher, D.A.; Barnard, P.O.; Truong, T.P. The role of stated preference methods in studies of travel choice. J. Transp. Econ. Policy 1988, 22, 45-58.

35. Louviere, J.J. Experimental choice analysis: Introduction and overview. J. Bus. Res. 1992, 24, 89-95. [CrossRef]

36. Adamowicz, W.; Boxall, P.; Williams, M.; Louviere, J. Stated preference approaches for measuring passive use values: choice experiments and contingent valuation. Am. J. Agr. Econ. 1998, 80, 64-75. [CrossRef]

37. Birol, E.; Karousakis, K.; Koundouri, P. Using a choice experiment to account for preference heterogeneity in wetland attributes: The case of Cheimaditida wetland in Greece. Ecol. Econ. 2006, 60, 145-156. [CrossRef]

38. Christie, M.; Hanley, N.; Hynes, S. Valuing enhancements to forest recreation using choice experiment and contingent behaviour methods. J. Forest Econ. 2007, 13, 75-102. [CrossRef]

39. Lee, W.S.; Bae, S.Y.; Moon, J.H. Benefits and preferences for a hiking trail using a Choice Experiment. J. Tour. Leis. Res. 2015, 27, 5-24.

40. Lee, W.S. Development of a Personal Values Scale and Non-Asian Tourists' Preferred Attributes for a One Day Seoul Tour Package: Discrete Choice Experiment. Available online: http://kiss.kstudy.com/thesis/thesisview.asp?key=3353038 (accessed on 28 June 2019).

41. Balcombe, K.; Fraser, I.; Harris, L. Consumer willingness to pay for in-flight service and comfort levels: A choice experiment. J. Air Transp. Manag. 2009, 15, 221-226. [CrossRef]

42. Chou, C.-J.; Chen, P.-C. Preferences and willingness to pay for green hotel attributes in tourist choice behavior: The case of Taiwan. J. Travel Tour. Mark. 2014, 31, 937-957.

43. Hearne, R.R.; Salinas, Z.M. The use of choice experiments in the analysis of tourist preferences for ecotourism development in Costa Rica. J. Environ. Manag. 2002, 65, 153-163. [CrossRef]

44. Masiero, L.; Heo, C.Y.; Pan, B. Determining guests' willingness to pay for hotel room attributes with a discrete choice model. Int. J. Hosp. Manag. 2015, 49, 117-124. [CrossRef]

45. Chang, R.C.; Kivela, J.; Mak, A.H. Food preferences of Chinese tourists. Ann. Tour. Res. 2010, 37, 989-1011. [CrossRef]

46. Adamowicz, W.; Louviere, J.; Swait, J. Introduction to Attribute-Based Stated Choice Methods; National Oceanic Athmospheric Administration (NOAA): Washington, WA, USA, 1998.

47. McFadden, D. The measurement of urban travel demand. J. Public Econ. 1974, 3, 303-328. [CrossRef]

48. Louviere, J.J. Analyzing Decision Making: Metric Conjoint Analysis; SAGE Publications: Thousand Oaks, CA, USA, 1988.

49. Apostolakis, A.; Jaffry, S. A choice modeling application for Greek heritage attractions. J. Travel Res. 2005, 43, 309-318. [CrossRef]

50. Ben-Akiva, M.; Lerman, S.R. Discrete Choice Analysis: Theory and Application to Travel Demand; The MIT Press: Cambridge, MA, USA, 1985.

51. Global Times. China's Cruise Industry Sails Smoothly, Making Transition from Fast to Quality Growth. Available online: http://www.globaltimes.cn/content/1137710.shtml (accessed on 3 May 2019).

52. Korea Tourism, Organization. Available online: https://kto.visitkorea.or.kr/kor/notice/data/report/org/board/ view.kto?id=420555\&instanceId=127 (accessed on 12 May 2019).

53. Jones, R.V. Motivations to cruise: an itinerary and cruise experience study. J. Hosp. Tour. Manag. 2011, 18, 30-40. [CrossRef] 
54. Hwang, J.; Han, H. A study on the application of the experience economy to luxury cruise passengers. Tour. Hosp. Res. 2018, 18, 478-491. [CrossRef]

55. Klein, R.A. Keeping the cruise tourism responsible: The challenge for ports to maintain high self esteem. In Proceedings of the International Conference for Responsible Tourism in Destinations, Belmopan, Belize, 19-23 October 2009; Volume 22.

56. Chen, J.M.; Neuts, B.; Nijkamp, P.; Liu, J. Demand determinants of cruise tourists in competitive markets: Motivation, preference and intention. Tour. Econ. 2016, 22, 227-253. [CrossRef]

57. Princess Cruises. Available online: http://www.princess.inspiramedia.com/plan-cruise/china-itineraries/ (accessed on 12 May 2019).

58. Klein, R.A. Responsible cruise tourism: Issues of cruise tourism and sustainability. J. Hosp. Tour. Manag. 2011, 18, 107-116. [CrossRef]

59. Weeden, C.; Lester, J.-A.; Thyne, M. Cruise tourism: Emerging issues and implications for a maturing industry. J. Hos. Tour Manag. 2011, 18, 26-29. [CrossRef]

60. Lester, J.-A.; Weeden, C. Stakeholders, the natural environment and the future of Caribbean cruise tourism. Int. J. Tour. Res. 2004, 1, 39-50. [CrossRef]

61. Petrick, J.F.; Li, X. What Drives Cruise Passengers' Perceptions of Value. 2006, pp. 63-73. Available online: https://www.cabdirect.org/cabdirect/abstract/20063157059 (accessed on 28 June 2019).

(C) 2019 by the authors. Licensee MDPI, Basel, Switzerland. This article is an open access article distributed under the terms and conditions of the Creative Commons Attribution (CC BY) license (http://creativecommons.org/licenses/by/4.0/). 